\title{
Weed phytosociological in irrigated rice under different cultivation systems and crop rotation intensity
}

\section{André da Rosa Ulguim ${ }^{*}$ Filipe Selau Carlos $^{2} \odot$ Rodrigo Areze da Silva Santos ${ }^{3}$ Alencar Junior Zanon ${ }^{4}$ (-) Isabel Schlegel Werle ${ }^{5}$ ') Mattheus Beck ${ }^{3}$}

${ }^{1}$ Departamento de Defesa Fitossanitária, Universidade Federal de Santa Maria (UFSM), 97105-900, Santa Maria, RS, Brasil. E-mail: andre.ulguim@ufsm.br. "Corresponding author.

${ }^{2}$ Universidade Federal de Pelotas (UFPEL), Pelotas, RS, Brasil.

${ }^{3}$ Instituto Rio Grandense do Arroz (EEA/IRGA), Cachoeirinha, RS, Brasil.

${ }^{4}$ Departamento de Fitotecnia, Universidade Federal de Santa Maria (UFSM), Santa Maria, RS, Brasil.

${ }^{5}$ Universidade Federal de Santa Maria (UFSM), Santa Maria, RS, Brasil.

ABSTRACT: This research aimed to evaluate the phytosociology of weeds in irrigated rice in different soil management systems and crop rotation intensity. Therefore, two field studies were carried out. Study 1 was conducted in an area that has been cultivated since 1994 with three cultivation systems: direct, pre-germinated and conventional ones. Study 2 was carried out in an experimental area in five Integrated Farming Systems, with crop rotation. Phytosociological evaluations were conducted when rice was fully blooming, in the first study, and when grain filling was ending, in the second study. Pre-germinated system of rice cultivation has predominance of aquatic weeds. Conventional system when compared with direct sowing has lower weed densities. Integrated Agricultural Production Systems with higher intensity of crop rotation have been higher infested of perennial species.

Key words: Oryza sativa, red rice, sustainable intensification.

Fitossociologia de plantas daninhas em arroz irrigado sob diferentes sistemas de cultivo e intensidade de rotação de culturas

RESUMO: Este trabalho teve por objetivo avaliar a fitossociologia de plantas daninhas em arroz irrigado em diferentes sistemas de manejo do solo e intensidade de rotação de culturas. Para tanto, foram conduzidos dois estudos de campo. O primeiro estudo foi realizado em área cultivada desde 1994 com três sistemas de cultivo: plantio direto, pré-germinado e sistema convencional. O segundo estudo foi realizado em área experimental sob cinco Sistemas Integrados de Produção Agropecuária, com rotação de culturas. As avaliações fitossociológicas foram realizadas quando o arroz estava em pleno florescimento no primeiro estudo, e no final do enchimento de grãos no segundo. O sistema prégerminado de cultivo de arroz apresenta predominância de plantas daninhas aquáticas. O sistema de cultivo convencional, quando comparado ao plantio direto, possui menores densidades de plantas daninhas. Nos Sistemas Integrados de Produção Agropecuária com maior intensidade de rotação de culturas houve maior infestação de plantas daninhas perenes.

Palavras-chave: Oryza sativa, arroz daninho, intensificação sustentável.

\section{INTRODUCTION}

The use of integrated management practices is an alternative to sustainable production of synergism between food, energy and fiber yield and environmental quality (LEMAIRE et al., 2014). From this perspective, irrigated rice cultivated in Rio Grande do Sul state (RS), in the South of Brazil, in an irrigation system by inundation, has been responsible for about $70 \%$ of the country's production. Its mean productivity has been $7.2 \mathrm{Mg} \mathrm{ha}^{-1}$ in the last decade (IRGA, 2017). It is higher than the world average, which is $4.5 \mathrm{Mg} \mathrm{ha}{ }^{-1}$, but lower than the potential of cultivars found in the market these days, since they may yield $14 \mathrm{Mg} \mathrm{ha}^{-1}$ (RIBAS et al., 2016).
Increase in productivity of rice crops, both regionally and globally, requires the use of simple techniques, such as optimal sowing time, irrigation and maintenance of a homogeneous water layer, balanced fertilization and weed management. Weeds compete with the rice culture for light, water and nutrients and may be alternative hosts for plagues and diseases (CONCENÇO et al., 2014). As a result, they stand out as one of the main factors that lead to decrease in productivity (SCHAEDLER et al., 2013), since losses can reach $85 \%$.

The cultivation system may influence the weed population, since every system has specific characteristics which may, or not, favor the development of the species. It is hard to control 
some weed species with herbicides because of their morphophysiological similarity to rice. An example is red rice (Oryza sativa) (SHIVRAIN et al., 2010), which occurs frequently and is widely distributed in the regions that yield this cereal grain.

The basis to plan an efficient proposal for integrated management is knowledge about the community of weeds reported in production areas and about the cultivation system used in those areas. These data can be obtained by phytosociological studies which aim to identify the composition and distribution of species in a certain community of plants (CONCENÇO et al., 2014), so as to enable interferences in the flora under study. In addition, management alternatives, such as use of different cultivation systems and crop rotation, cause great impact on many species of weeds, an advantage in terms of economy and sustainability. Therefore, this study aimed to evaluate the weed phytosociology in irrigated rice under different cultivation systems and crop rotation intensity.

\section{MATERIALS AND METHODS}

Two studies were carried out in the 2016/2017 growing season. Study 1 was conducted at the Experimental Station of the Rio Grande do Sul Rice Institute (EEA/IRGA), an experimental center located in Cachoeirinha, RS, Brazil. The soil of the study has been classified as Haplic Gleysol (EMBRAPA, 2013). The experimental design consisted of randomized blocks with three replications and experimental units were $1120 \mathrm{~m}^{2}$. The treatment factor consisted of the following cultivation systems: direct (sowing without tilling the soil after the harvest of the summer culture), pre-germinated (all rice cultivation occurs with a water layer) and conventional (the soil is tilled after harvest and before sowing) ones. The cultivar used in the 2016/2017 season was IRGA 424. Treatments complied with recommendations issued for that culture (SOSBAI, 2016), and was applied penoxsulam (48g a.i. ha $\left.{ }^{-1}\right)$ herbicide when rice crop was with four leaves.

Study 2 was carried out in a flat area whose soil has been classified as Eutrophic Haplic Plansol (EMBRAPA, 2013), in Cristal, RS, Brazil. The experimental design consisted of randomized blocks with three replications and units ranged from 0.8 to 1.5 hectares. This design has been conducted since the 2013/2014 season in different integrated crop-livestock systems. Treatments consisted of the following levels with combinations of soil preparation, culture diversity (in time and space) and rice cultivation intensity (in time) (Table 1): S1, Standard System (SS), with continuous rice cultivation and annual soil mobilization, without grazing in the winter; S2, fast succession with low diversity, high intensity of rice cultivation and minimum soil mobilization; S3, fast rotation with moderate diversity and minimum soil mobilization; S4, high diversity of commercial crops, low rice cultivation intensity and minimal soil mobilization; and S5, high diversity of forage species, low intensity of rice cultivation and minimal soil mobilization (CARMONA et al., 2018). The cultures were rice (Oryza sativa L.), ryegrass (Lolium multiflorum L.), bird foot trefoil (Lotus corniculatus L.), sudangrass (Sorghum sudanense (Piper) Stapf), soybeans (Glycine max L.), corn (Zea mays L.) and white clove (Trifolium repens L.).

System $1(\mathrm{~S} 1)$ is considered the control treatment whereas the others (S2, S3, S4 and S5) are different variations of the Integrated Farming Systems (IFS) which are recommended for rice cultures. All treatments given to the rice culture were carried out by direct sow-

Table 1 - Spatial-temporal distribution in systems of culture diversity and intensity of irrigated rice cultivation.

\begin{tabular}{|c|c|c|c|c|c|c|c|c|c|c|}
\hline \multirow{2}{*}{ Systems } & \multicolumn{2}{|c|}{----------2013---------- } & \multicolumn{2}{|c|}{----------2014--------- } & \multicolumn{2}{|c|}{-----------2015--------- } & \multicolumn{2}{|c|}{-----------2016--------- } & \multicolumn{2}{|c|}{-----------2017---------- } \\
\hline & Wint. ${ }^{1}$ & Sum. & Wint. & Sum. & Wint. & Sum. & Wint. & Sum. & Wint. & Sum. \\
\hline S1 & $\mathrm{Rs}^{2}$ & $\mathrm{R}$ & Rs & $\mathrm{R}$ & Rs & $\mathrm{R}$ & Rs & $\mathrm{R}$ & Rs & $\mathrm{R}$ \\
\hline S2 & $\mathrm{Rg}$ & $\mathrm{R}$ & $\mathrm{Rg}$ & $\mathrm{R}$ & $\mathrm{Rg}$ & $\mathrm{R}$ & $\mathrm{Rg}$ & $\mathrm{R}$ & $\mathrm{Rg}$ & $\mathrm{R}$ \\
\hline S3 & $\mathrm{Rg}$ & $\mathrm{Sb}$ & $\mathrm{Rg}$ & $\mathrm{R}$ & $\mathrm{Rg}$ & $\mathrm{Sb}$ & $\mathrm{Rg}$ & $\mathrm{R}$ & $\mathrm{Rg}$ & $\mathrm{Sb}$ \\
\hline S4 & $\mathrm{Rg} / \mathrm{Wc}$ & $\mathrm{Sg}$ & $\mathrm{Rg} / \mathrm{Wc}$ & $\mathrm{Sb}$ & $\mathrm{Rg} / \mathrm{Wc}$ & $\mathrm{C}$ & $\mathrm{Rg} / \mathrm{Wc}$ & $\mathrm{R}$ & $\mathrm{Rg} / \mathrm{Wc}$ & $\mathrm{Sg}$ \\
\hline S5 & $\mathrm{Rg} / \mathrm{Wc} / \mathrm{Bg}$ & $\mathrm{Sf}$ & $\mathrm{Rg} / \mathrm{Wc} / \mathrm{Bg}$ & $\mathrm{Sf}$ & $\mathrm{Rg} / \mathrm{Wc} / \mathrm{Bg}$ & Sf & $\mathrm{Rg} / \mathrm{Wc} / \mathrm{Bg}$ & $\mathrm{R}$ & $\mathrm{Rg} / \mathrm{Wc} / \mathrm{Bg}$ & $\mathrm{Sf}$ \\
\hline
\end{tabular}

${ }^{1}$ Wint. $=$ Winter; Sum. $=$ Summer. ${ }^{2} \mathrm{Rs}=$ Rice stubble; Rg $=$ Ryegrass; Rg/Wc $=$ Ryegrass and White clove; Rg/Wc/Bg $=\mathrm{Ryegrass}, \mathrm{White}$ 
ing (absence of soil preparation), associated with grazing, except S1, whose system was conventional. Sowing of winter pastures was conducted in March and April in both years, in S2, S3, S4 and S5. In these systems, the method used was continuous grazing with variable stocking. The pasture was desiccated 30 days before rice sowing in S2, S3, S4 and S5. The rice cultivar used in the 2016/2017 season was IRGA 424 RI.

The phytosociological study comprised 10 random samplings per experimental unit with a frame that covered $0.25 \mathrm{~m}^{2}$, when irrigated rice was blooming (Study 1) and when grain filling was ending (Study 2).The difference in the evaluation period in the experiments was due to the sowing date in the sites, and logistic and the geographic distance to carry out analysis. Every sample had its individuals counted and its species identified. Based on quantitative data on the species, the following phytosociological variables were calculated: frequency, density, abundance, relative frequency, relative density, relative abundance and importance value index. Calculation of characteristics under evaluation was carried out by formulas proposed by MUELLER-DOMBOIS and ELLENBERG (1974), as follows:

Frequency $(\mathrm{Fr})=$ number of squares that contain the species/total number of squares

Density $(\mathrm{De})=$ total number of individuals/ total area of the sample $\left(0.25 \mathrm{~m}^{2}\right)$

Abundance $(\mathrm{Ab})=$ number of individuals per species/number of squares that contain the species

Relative frequency $(\mathrm{RFr})=$ frequency $\mathrm{x}$ 100/total frequency of all species

Relative density $(\mathrm{RDe})=$ density of the species x 100/total density of the species

Relative Abundance (RAb) = abundance of the species $\mathrm{x} 100 /$ total abundance of the species Importance Value Index (IVI) $=\mathrm{RFr}+\mathrm{RDe}+\mathrm{RAb}$

The calculation of frequency $(\mathrm{Fr})$ evaluates the distribution of the species in the squares, density (De) determines the quantity of plants of each species per area unit and abundance (Ab) shows the concentration of the species in the area. Associations of these variables - relative frequency ( $\mathrm{RFr}$ ), relative density (RDe) and relative abundance (RAb) provide information about the relation of each species with the other species reported in the area whereas the Importance Value Index (IVI) shows which species are the most important ones in the study area.

\section{RESULTS AND DISCUSSION}

Six species of weeds - distributed in three botanic families - were identified by Study 1 since they infested the culture of irrigated rice: red rice (Oryza sativa L.) and buffalo grass (Panicum maximum Jacq.) (Poaceae family); small-flowered nutsedge (Cyperus difformis L.) and yellow nutsedge (Cyperus esculentus L.) (Cyperaceae family); and Guyanese arrowhead (Sagittaria guyanensis Kunth) and California arrowhead (Sagittaria montevidensis Cham \& Schlecht) (Alismataceae family) (Table 2). Oryza sativa, Cyperus difformis and Sagittaria guyanensis were reported by the evaluation in all cultivation systems.

Weed species had their highest densities in the pre-germinated system, except Panicum maximum and Cyperus esculentus, which were only reported in the conventional and direct systems, respectively. In the pre-germinated system, there was higher density of aquatic weeds, such as Sagittaria guyanensis and Sagittaria montevidensis (Table 2), due to the fact that such species are benefited by lack of tillage and by soil saturation or inundation caused by the pre-germinated system. Regarding aquatic species, Sagittaria montevidensis stands out because it is a rhizomatous species which adapts to the ecological amplitude. When it is not controlled, a broad amount of seeds can develop on the soil and contribute to increase the population in the next season (CASSOL et al., 2008).

The lowest value of density was found in the conventional system, results from mechanical operations of early soil preparation and mobilization (Table 2). They stimulated seed germination and emergence, which can be controlled; thus, the seedbank may be reduced in the soil (SOSBAI, 2016). Besides, soils without plant cover usually have higher temperature amplitude than soils protected by plant residues, thus, stimulating the germination process (VINCENSI et al., 2011), predation, deterioration and transport by several agents, which also contributes to reduce the seedbank. However, the conventional system made Oryza sativa have the highest values of importance value index, relative density and relative frequency. Besides being hard to control, Oryza sativa is also highly persistent in rice fields, due to seed dormancy and high longevity in the soil (THURBER et al., 2010).

This problem has been aggravated by conventional sowing since it constantly feeds the seedbank and favors Oryza sativa emergence by comparison with the pre-germinated system (CHAUHAN et al., 2013). The amount and diversity of the seed bank in the soil may undergo changes in different production systems and soil management (PACHECO et al., 2016). Therefore, in areas infested by Oryza sativa, the use of distinct cultivation systems and crop rotation are highly recommended 
Table 2 - Phytosociology of weeds in irrigated rice cultures as the result of different soil management systems.

\begin{tabular}{|c|c|c|c|c|c|c|c|}
\hline Plant species & $\mathrm{Fr}^{1}$ & $\left.\operatorname{De}(\mathrm{pl} \mathrm{m})^{2}\right)$ & $\mathrm{Ab}$ & RFr (\%) & RDe $(\%)$ & $\mathrm{RAb}(\%)$ & IVI \\
\hline \multicolumn{8}{|c|}{-----------------------------------------------------------------------Conventional Preparation----------------------------------------------------------------- } \\
\hline Oryza sativa & 0.13 & 16 & 1.00 & 37 & 36 & 20 & 93 \\
\hline Cyperus difformis & 0.03 & 4 & 1.00 & 9 & 9 & 20 & 38 \\
\hline Sagittaria guyanensis & 0.10 & 12 & 1.00 & 28 & 28 & 20 & 75 \\
\hline Panicum maximum & 0.03 & 4 & 1.00 & 9 & 9 & 20 & 38 \\
\hline Sagittaria montevidensis & 0.07 & 8 & 1.00 & 18 & 18 & 20 & 56 \\
\hline \multicolumn{8}{|c|}{ 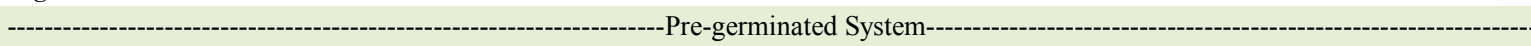 } \\
\hline Oryza sativa & 0.23 & 32 & 1.14 & 35 & 19 & 11 & 65 \\
\hline Cyperus difformis & 0.10 & 68 & 5.67 & 15 & 41 & 55 & 111 \\
\hline Sagittaria guyanensis & 0.17 & 32 & 1.60 & 25 & 19 & 16 & 60 \\
\hline Sagittaria montevidensis & 0.17 & 36 & 1.80 & 25 & 21 & 18 & 64 \\
\hline \multicolumn{8}{|c|}{ o } \\
\hline Oryza sativa & 0.13 & 16 & 1.00 & 29 & 19 & 16 & 64 \\
\hline Cyperus difformis & 0.17 & 44 & 2.20 & 35 & 52 & 36 & 123 \\
\hline Sagittaria guyanensis & 0.13 & 16 & 1.00 & 29 & 19 & 16 & 64 \\
\hline Cyperus esculentus & 0.03 & 8 & 2.00 & 7 & 10 & 32 & 49 \\
\hline
\end{tabular}

${ }^{1}$ Frequency $(\mathrm{Fr})$, density (De), abundance $(\mathrm{Ab})$, relative frequency (RFr), relative density (RDe), relative abundance (RAb) and importance value index (IVI).

so as to manage this weed efficiently. In direct sowing, with no tillage, Oryza sativa infestation tends to decrease, since viable seeds are not brought from deep soil layers to the most superficial ones and the species emergence is avoided (SOSBAI, 2016). These data corroborate results reported by this study regarding the lower density of Oryza sativa in this system (Table 2). Systems that maintain soil cover, such as minimum tillage and direct sowing, affect the development of gramineous plants (SOARES et al., 2016). Infestation by these species virtually disappears when soil management is conservative.

However, Cyperus esculentus plants were only reported in the direct sowing system (Table 2), a fact that may result from the vegetative propagation of this species. It is favored by this system, since there is no tillage. Studies of rice crop showed that species of the Cyperaceae family dominated the seedbank in the soil (MESQUITA et al., 2013).

In Study 2, the following weeds were identified: Oryza sativa, barnyard grass (Echinochloa spp.), goosegrass [Eleusine indica (L.) Gaertn.] and Panicum maximum (Poaceae Family); rice flatsedge (Cyperus iria L.) and Cyperus esculentus (Cyperaceae family); joint vetch (Aeschynomene denticulata Rudd.) (Fabaceae family); and alligator weed [Alternanthera philoxeroides (Mart.) Griseb] (Amaranthaceae family). Species of Oryza sativa, Echinochloa spp. and Cyperus iria were reported in all systems.
Both S1 and S2 systems, which converged to rice monoculture, had the highest densities of weeds (Table 3). The S1 was conducted as conventional preparation and continuous rice without Lolium multiflorum nor pasturage in fall-winter, whereas S2 was conducted in direct sowing and continuous rice with Lolium multiflorum as a pasture in fall-winter (Table 1). In this case, apparently, as soil preparation and as the cover crop on fall-winter is lesser important to weed infestation than continuous rice on area. As mentioned above, infestation of some weed families can be reduced as a function of conservative soil management, what can be observed on S2 that Eleusine indica was not reported while Aeschynomene denticulata infestation was detected, changing plant from Poacea to Fabacea family (Table 3).

Cyperus iria had the highest values of importance value index, density, frequency, relative abundance and relative density in S1. They decreased up to S5 from 164 (average S1 and S2) to 79 (average $\mathrm{S} 3, \mathrm{~S} 4$ and S5) plants $\mathrm{m}^{-2}$, depending on the increase in the system diversification (Table 3 ), showing the importance of crop rotation to weed management. Studies of direct sowing fields with Arachis hypogaea L. crop rotation, in which Cyperus rotundus L. stood out among the weeds, showed that conservative soil management and crop rotation mitigated problems resulting from this species (SOARES et al., 2016). This result may be attributed to the fact that some 
Table 3 - Phytosociology of weeds in irrigated rice cultures at different levels of soil preparation, culture diversity (in time and space) and intensity of rice cultivation (in time) in long-lasting cultivation systems.

\begin{tabular}{|c|c|c|c|c|c|c|c|}
\hline Plant species & $\operatorname{Fr}^{1}$ & $\operatorname{De}\left(\mathrm{pl} \mathrm{m}{ }^{2}\right)$ & $\mathrm{Ab}$ & $\operatorname{RFr}(\%)$ & RDe $(\%)$ & $\mathrm{RAb}(\%)$ & IVI \\
\hline Oryza sativa & 0.47 & 128 & 2.3 & 34 & 32 & 21 & 87 \\
\hline Cyperus iria & 0.67 & 208 & 2.6 & 49 & 52 & 24 & 125 \\
\hline Echinochloa spp. & 0.20 & 48 & 2.0 & 15 & 12 & 18 & 45 \\
\hline Eleusine indica & 0.03 & 16 & 4.0 & 2 & 4 & 37 & 43 \\
\hline \multicolumn{8}{|c|}{ 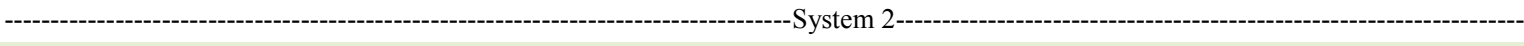 } \\
\hline Oryza sativa & 0.43 & 148 & 2.8 & 33 & 36 & 29 & 99 \\
\hline Cyperus iria & 0.43 & 120 & 2.3 & 33 & 29 & 23 & 86 \\
\hline Echinochloa spp. & 0.33 & 120 & 3.0 & 26 & 29 & 31 & 86 \\
\hline Aeschynomene denticulata & 0.10 & 20 & 1.7 & 8 & 6 & 17 & 29 \\
\hline \multicolumn{8}{|c|}{ - } \\
\hline Oryza sativa & 0.20 & 28 & 1.2 & 19 & 8 & 9 & 37 \\
\hline Cyperus iria & 0.27 & 80 & 2.5 & 26 & 24 & 20 & 69 \\
\hline Echinochloa spp. & 0.27 & 32 & 1.0 & 26 & 10 & 8 & 43 \\
\hline Alternanthera philoxeroides & 0.27 & 188 & 5.9 & 26 & 56 & 47 & 129 \\
\hline Eleusine indica & 0.03 & 8 & 2.0 & 3 & 2 & 16 & 22 \\
\hline \multicolumn{8}{|c|}{ 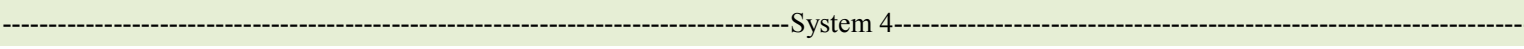 } \\
\hline Oryza sativa & 0,03 & 4 & 1.0 & 5 & 2 & 5 & 12 \\
\hline Cyperus iria & 0.13 & 80 & 5.0 & 21 & 35 & 26 & 81 \\
\hline Echinochloa spp. & 0.23 & 52 & 1.9 & 37 & 22 & 10 & 69 \\
\hline Alternanthera philoxeroides & 0.07 & 72 & 9.0 & 11 & 31 & 46 & 88 \\
\hline Cyperus esculentus & 0.07 & 12 & 1.5 & 10 & 5 & 8 & 24 \\
\hline Eleusine indica & 0.10 & 12 & 1.0 & 16 & 5 & 5 & 26 \\
\hline \multicolumn{8}{|c|}{ 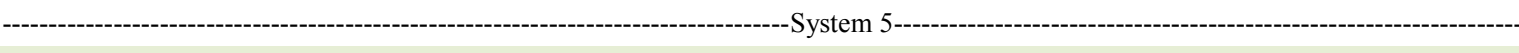 } \\
\hline Oryza sativa & 0.13 & 36 & 2.3 & 15 & 12 & 15 & 41 \\
\hline Cyperus iria & 0.20 & 76 & 3.2 & 22 & 25 & 20 & 67 \\
\hline Echinochloa spp. & 0.23 & 36 & 1.3 & 26 & 12 & 8 & 46 \\
\hline Alternanthera philoxeroides & 0.23 & 136 & 4.9 & 26 & 44 & 31 & 101 \\
\hline Panicum maximum & 0.07 & 16 & 2.0 & 7 & 5 & 13 & 26 \\
\hline Eleusine indica & 0,03 & 8 & 2,0 & 4 & 2 & 13 & 19 \\
\hline
\end{tabular}

${ }^{1}$ Frequency $(\mathrm{Fr})$, density (De), abundance $(\mathrm{Ab})$, relative frequency $(\mathrm{RFr})$, relative density (RDe), relative abundance (RAb) and importance value index (IVI).

species, such as C. rotundus, are more sensitive to light, which interferes in the germination of their propagules (ALBUQUERQUE et al. 2013). Thus, increase in residues on the soil harms their development.

In additional to maintenance of residues on soil surface, a study of [Sorghum bicolor (L.) Moench] showed that systems with high soil mobilization lead to high weed infestation, by comparison with areas with no preparation (NAGAHAMA et al., 2014). Most wild species develop mechanisms to avoid germination when seeds are not close to the surface of the soil. As a result, they account for their survival in unfavorable conditions. In the conventional system, due to plowing and harrowing operations, seeds of weeds that are deep in the soil can be transported to the surface, thus, enabling the germination process, which becomes more uniform in this condition (VERNETTI JUNIOR et al., 2005). Therefore, on the contrary of what was observed by Study 1, in order to make conventional cultivation feasible the 
management measures after sowing must be highly efficient to avoid high densities of weeds competing with the culture, a fact that was observed by Study 2 on $\mathrm{S} 1$ e $\mathrm{S} 2$ systems.

Systems with minimum tillage and direct sowing are able to decrease the general density of weeds, by comparison with the conventional system (VERNETTI JUNIOR et al., 2005). Studies of Arachis hypogaea L. showed that the use of direct sowing can decrease the number of weeds in $40 \%$, both in fallow lands and in areas of peanut cultivation (SOARES et al., 2016). Crop rotation, with the help of direct sowing, can become an excellent tool to manage seedbanks.

In integrated systems S3, S4 and S5, which are based on direct sowing with minimum tillage and mainly on culture diversification, perennial weeds, such as Alternanthera philoxeroides, were reported (Table 3). Besides, in general, values of relative abundance and importance value index of this weed were found to be higher than the ones of the other species in these systems (Table 3). The germination process of weed seeds in the direct sowing system requires more time because there are plant residues on the soil and the physical effect of the thatch prevents the contact of the seedling with light (MESQUITA et al., 2013; NAGAHAMA et al., 2014). Thus, those positive photoblastic annual weeds tend to lose space to perennial species, with vegetative reproduction. This is an important issue to observe in systems with direct sowing and crop diversity, related to change in weed flora in function of niche specialization, which we can show by presence of Panicum maximum on $\mathrm{S} 5$, probably associated with forage species used in this system. In this case, is very important to farmers be careful to weed species present on area, to choose the better method of control after sowing, once some of these species is very difficult to control.

Based on results reported by this study, it may be inferred that conventional management systems in irrigated rice production tend to have high densities of weeds, mainly Oryza sativa, whereas systems that converge to direct sowing, with crop rotation and culture diversification, are efficient at mitigating weed infestation. In addition, crop rotation is indispensable to mitigate weed infestation in areas where direct sowing is conducted. Therefore, this study showed that the association of crop rotation with direct sowing was the main factor to manage infesters, since they decreased their general density, by comparison with monoculture practices. The use of integrated methods that aim enabling the culture to have advantages over weeds is a viable alternative to mitigate the use of herbicides and decrease production costs in irrigated rice.

\section{CONCLUSION}

Aquatic weeds, such as species of the genus Sagittaria, predominate in pre-germinated systems of rice cultivation. Cultivation systems that do not use conventional soil preparation have low importance value index of Oryza sativa; thus, they can be used to manage the species. Integrated Farming Systems with high intensity of crop rotation represent potential strategies to mitigate infestation by weeds; however, can be higher infested with of perennial species.

\section{DECLARATION OF CONFLICTING INTERESTS}

The authors declare no conflict of interest. The founding sponsors had no role in the design of the study; in the collection, analyses, or interpretation of data; in the writing of the manuscript, and in the decision to publish the results.

\section{AUTHORS' CONTRIBUTIONS}

The authors contributed equally to the manuscript.

\section{REFERENCES}

ALBUQUERQUE, J. A. A. et al. Phytosociology and morphological characteristics of weeds after corn cropping on conventional till in the savanna of Roraima. Revista Agroambiente, v. 7, n. 3, p. 313-321, 2013. Available from: <https://www.researchgate.net/ publication/284911657_Fitossociologia_e_caracteristicas_morfologicas_de_plantas_daninhas_apos_cultivo_de_milho_em_plantio_convencional_no_cerrado_de_Roraima>. Accessed: Feb. 01, 2018. doi: $10.18227 / \overline{1} 982-8470$ ragro.v7i3.1392.

CARMONA, F.C. et al. Sistemas integrados de produção agropecuária em terras baixas: a integração lavoura-pecuária como o caminho da intensificação sustentável da lavoura arrozeira. Editora RJR: Porto Alegre, 2018. 180 p.

CASSOL, B. et al Morphological analysis of Sagittaria montevidensis developed under Different flooding conditions. Planta Daninha, v.26, p. 487-496, 2008. Available from: <http://www.scielo.br/scielo.php?pid=S0100-83582008000300003\&script $=$ sci abstract\&tlng=pt $>$. Accessed: Feb. 02, 2018. doi: 10.1590/S010083582008000300003 .

CHAUHAN, B.S. et al. Weedy rice: an emerging threat for directseeded rice production systems in India. Journal of Rice Research, v.1, p.106, 2013. Available from: <https://www.omicsonline.org/ open-access/weedy-rice-an-emerging-threat-for-directseeded-riceproduction-systems-in-india-jrr.1000106.php?aid=18970>. Accessed: Jan. 31, 2018. doi: 10.4172/jrr.1000106.

CONCENÇO, G. et al. Phytosociological surveys: tools for weed science. Planta Daninha, v. 31, n. 2, p. 469-482, 2014. Available from: <file://C:/Users/Principal/Desktop/../Desktop/TCC/CONCEN- 
ÇO $\% 20$ et $\% 20$ al. $\% 2 c \% 202014$.pdfTCC/CONCEN\%C3\%87O $\% 20$ et $\% 20$ al.\%252c\%202014.pdf>. Accessed: Jan. 30, 2018 doi: $10.1590 / \mathrm{S} 0100-83582013000200025$.

EMBRAPA. Sistema Brasileiro de Classificação de Solos. $\left(3^{\mathrm{a}}\right.$ Ed.). Embrapa, 2013. 353 f.

IRGA. Instituto Rio-Grandense do Arroz. Safras: Série histórica de Produção x Produtividade: BR x RS. Available from: <http://www. irga.rs.gov.br/conteudo/4215/safras>. Accessed: Nov. 19, 2017.

LEMAIRE, G. et al. Integrated crop-livestock systems: strategies to achieve synergy between agricultural production and environmental quality. Agriculture, Ecosystems \& Environment, v.190, p.4-8, 2014. Available from: <https://www.sciencedirect. com/science/article/pii/S0167880913002697>. Accessed: Feb. 15, 2018. doi:10.1016/j.agee.2013.08.009.

MESQUITA, M. L. et al. Floristic diversity of the soil weed seed bank in a rice-growing area of Brazil: in situ and ex situ evaluation. Acta Botanica Brasilica. v. 27, n.3, p. 465-471. 2013. Available from: $<$ http://www.scielo.br/pdf/abb/v27n3/v27n3a01.pdf $>$. Accessed: Feb. 01, 2018. doi: 10.1590/S0102-33062013000300001.

MUELLER-DOMBOIS, D.; ELLENBERGET,H. Aims and methods of vegetation ecology. New York: John Wiley, p. 574, 1974. Available from: <https://www.researchgate.net/publication/259466952_Aims and methods_of_vegetation_ecology>.Accessed: Feb. 02, 2018.

NAGAHAMA, H.J. et al. Dynamics and spatial variability of weeds under soil tillage systems in forage sorghum. Planta Daninha, v. 32, n.2, p.265-274, 2014. Available from: <http://www.scielo.br/scielo.php?script $=$ sci arttext\&pid $=\mathrm{S} 0100-83582014000200003>$. Accessed: Feb. 02, 2018. doi: 10.1590/S0100-83582014000200003.

PACHECO, L.P. et al. Production systems and weed control in annual crops of the Cerrado area of the State of Piauí. Revista Ciência Agronômica, v.47, n.3, p.500-8, 2016. Available from: <http:// www.scielo.br/pdf/rca/v47n3/1806-6690-rca-47-03-0500.pdf $>$. Accessed: Feb. 02, 2018.
RIBAS, G.G. et al. Accumulated dry matter and grain yield in flooded hybrid rice simulated with the SimulArroz model. Pesquisa Agropecuária Brasileira, v. 51, p.1907-1917, 2016. Available from: $<$ http://www.scielo.br/scielo.php?script=sci arttext\&pid=S0100204X2016001201907\&lng=pt\&tlng=pt $>$. Accessed: Jan. 16, 2018. doi: 10.1590/S0101-31222003000100014.

SHIVRAIN, V. K. et al. Diversity of weedy red rice (Oryza sativa L.) in Arkansas: USA in relation to weed management. Weed Research, v.50, p.289-302, 2010. Available from: $<$ https://www.scopus.com/ record/display.uri?eid=2-s2.0-77956406414\&origin=inward\&txGid $=044 \mathrm{ad} 741 \mathrm{fle}$ e $2 \mathrm{cb} 00 \mathrm{ccfdb} 280 \mathrm{a} 126 \mathrm{~b} 67>$. Accessed: 31 jan. 2018. doi; 10.1111/j.1365-3180.2010.00780.x.

SOARES, M. B. B. et al. Weed community in a raw sugarcane renovation area submitted to different soil managements. Planta Daninha, v.34, p. 91-98, 2016. Available from: $<$ http://www.scielo.br/ scielo.php?script $=$ sci arttext\&pid $=$ S0100-83582016000100091\&ln $\mathrm{g}=$ en\&nrm=iso\&tlng=en>. Accessed: Jan. 31, 2018. doi: 10.1590/ S0100-83582016340100009.

SOSBAI. In: XXXI Reunião Técnica da Cultura do Arroz Irrigado. SOSBAI, 2016. $200 \mathrm{f}$.

THURBER C. S. et al. Molecular evolution of shattering loci in U.S. weedy rice. Molecular Ecology, v.19, p.3271-3284, 2010. Available from: <https://www.ncbi.nlm.nih.gov/pmc/articles/PMC2988683/>. Accessed: Jan. 31, 2018. doi: 10.1111/j.1365-294X.2010.04708.x.

VERNETTI JUNIOR, F. de J. et al. Gramineous control in flooded areas. Revista Brasileira de Herbicidas, v. 4, n. 2, 2005. Available from: $<$ http://www.rbherbicidas.com.br/index.php/rbh/ article/viewFile/25/18>. Accessed: Dec. 15, 2017. doi: 10.7824/ rbh.v4i2.25.

VINCENSI, M. M. et al. Soil management and nitrogen fertilization on weed suppression on winter irrigated common bean. Revista Ciência Agronômica, v.42, p. 758-764, 2011. Available from: $<$ http://www.scielo.br/pdf/rca/v42n3/23.pdf $>$. Accessed: Jan. 31, 2018. doi: 10.1590/S1806-66902011000300023. 